\title{
6 The North Frisians and the Wadden Sea
}

\author{
Thomas Steensen
}

\begin{abstract}
The Wadden Sea is not the edge of North Frisia, it is not a marginal part, but an integral and central element. The district of North Frisia (Kreis Nordfriesland), founded in 1970, covers an area of 2,083 square kilometres. To that must be added the Wadden region between the Eider River and the Lister Tief, covering an area of about 1,750 square kilometres. North Frisia consists of 55 percent land and no less than 45 percent mudflats. The Wadden Sea, especially the North Frisian part of it, has been shaped by an interplay over centuries between man and his natural surroundings, a phenomenon that it difficult to find elsewhere in the world. Large parts of the Wadden Sea form a 'cemetery of the marshlands'. Kulturspuren (traces of culture) such as remains of terps and dikesdike, bricks, pottery shards, tidal gates, ditch systems, furrows, entire farming fields, and places of early salt peat extraction are a testament to the interdependence between man and nature. Archaeologist Hans Joachim Kühn considers this 'an inexhaustible archive of remembrance and research, sometimes even of shudder'. Throughout the centuries, there has been a special relationship between the North Frisians and the Wadden Sea. This is reflected by the intense discussions on the establishment of a national park. It really would have been appropriate if in 2009 the Wadden Sea had been recognised not only as a World Natural Heritage Site but also as a World Cultural Heritage Site. So far, this cultural landscape has not been sufficiently put into focus.
\end{abstract}

Keywords: Wadden Sea, North Frisia, traces of culture, national park, World Cultural Heritage

Egberts, Linde \& Schroor, Meindert (eds.), Waddenland Outstanding: The History, Landscape and Cultural Heritage of the Wadden Sea Region. Amsterdam: Amsterdam University Press, 2018 DOI: $10.5117 / 9789462986602 / \mathrm{CHO} 6$ 
North, East and West Frisia are all bordered by the Wadden Sea, that unique and peculiar region at the edge of the North Sea which, at the height of medieval Frisian trading (i.e., in Carolingian times), was sometimes called the Frisian Sea (Mare Frisicum). All Frisians have a special relationship to the Wadden Sea. This article gives an overview of the essence of the relation between the North Frisians and the Wadden Sea, from five different angles: landscape, literary imagination, traces of material culture, economics and the vicissitudes of conservation.

\section{The area: Interface between land and sea}

A brief glance at North Frisia's topography clarifies the special relationship between North Frisia and the Wadden Sea. The Wadden Sea is not on the edge of North Frisia; it is not a marginal part but rather an integral and central element. The district of North Frisia (Kreis Nordfriesland), founded in 1970 , covers an area of 2,083 square kilometres. But to this we must add the Wadden region between the Eider River and the Lister Tief covering an area of about $1,75^{\circ}$ square kilometres (50 square kilometres of foreland, $5^{0}$ square kilometres of sands, 1,100 square kilometres of waddenmudflats up to the sea level minus two metres and $55^{\circ}$ square kilometres of tidal currents). This adds up to a total of about 3,800 square kilometres. North Frisia consists of 55 percent land and no less than 45 percent wadden. Thus, the Wadden Sea can be considered a transitional region, an interface between the land and the sea in which — ignoring the man-made dikes - a boundary line between them hardly exists (LANCEWAD 2001; Schroor 2008; Steensen 2008, 2009). High tide and low tide make that clear twice a day. Even Roman writer Pliny the Elder (who actually had never been to North Frisia) expressed this fact in his Naturalis Historia (Book XVI, c. 1), as well as the antagonism between the sea and the land: 'Here, the ocean rises and falls twice within day and night, flooding an immense area. And in the end, when faced with this eternal struggle, no one can tell if this region belongs to land or sea.'

\section{Landscape: Constant change}

The Wadden Sea, especially the North Frisian part of it, has been shaped over centuries by an interplay between man and his natural surroundings that is found virtually nowhere else. Life and livelihood in a region threatened by the natural force of the sea, man's continuous struggle to secure and extend 
his territory, the sea continuously encroaching, constant changes, profit and loss - these are the fundamental themes. In some places, the areas of dry land have increased over the last millennium. In the Dithmarschen district, directly to the south of North Frisia, only Büsum had significant losses. North Frisia, however, irretrievably lost large parts of its medieval settlement area. This is the main signature of its history. The confrontation with the North Sea is a fundamentally classic Frisian theme. Wadden became marshland, and marshland wadden again, wadden turned into foreland and into a new Koog (salt marsh). A Koog could become a Hallig (island without protective dikes), some Halligen disappeared again, while new ones rose on wadden instead. Terps (artificial mounds) were raised and washed away again, entire settlements and villages were lost and sometimes refounded in another place (Müller 1917; Quedens 1975; Pingel 2000; Timrott \& Timrott 2013). In churches today we find altars, carved statues, and pulpits from churches destroyed by storm tides. Myths tell us about lost settlements; some say their church bells can still be heard today. Constant change is the central theme of the region. The Wadden Sea symbolises existential topics: growth and decay, existence and finiteness (Fischer 1997).

Like in a history book, examples of different epochs can be found along the North Frisian coast. A thousand years ago, the first terps and low dikes were built by Frisians in rural cooperatives. Innumerable wrecks in the Wadden Sea's sludge tell of intensive shipping. Memories of the epoch of the early modern states recall the planning and execution of profitable land reclamation, often with the assistance of Dutch experts. And in the previous century, there was the plan — highly ideologically motivated — during the era of National Socialism to reclaim the Wadden Sea for the Volk ohne Raum (People without Living Space).

Then there is the connection with other parts of the Wadden Sea region, partly an element of and partly transient to more southern parts of the Low Countries. One example of such a connection with the Low Countries is Johan van Wouwer, son of a merchant family from Antwerp, born in Hamburg in 1574. He studied and worked as a scientist in Germany, France, Italy and the Netherlands. At the court of Johann Adolf, the Duke of Gottorp, he became a minister of influence and was engaged in the dike construction in Eiderstedt. As a reward, the sovereign gave him land in that area. Johan van Wouwer died at the age of 38 , leaving no children. Even today, his marshland is owned by the foundation named after him. It promotes projects 'suited to enhancing the culture and region permanently'. To complete the circle, one of the projects supported by his foundation was the 'Waddenland - Outstanding' symposium held in Husum, Germany in December 2016. 
Figure 6.1 Hallig Habel on the horizon.

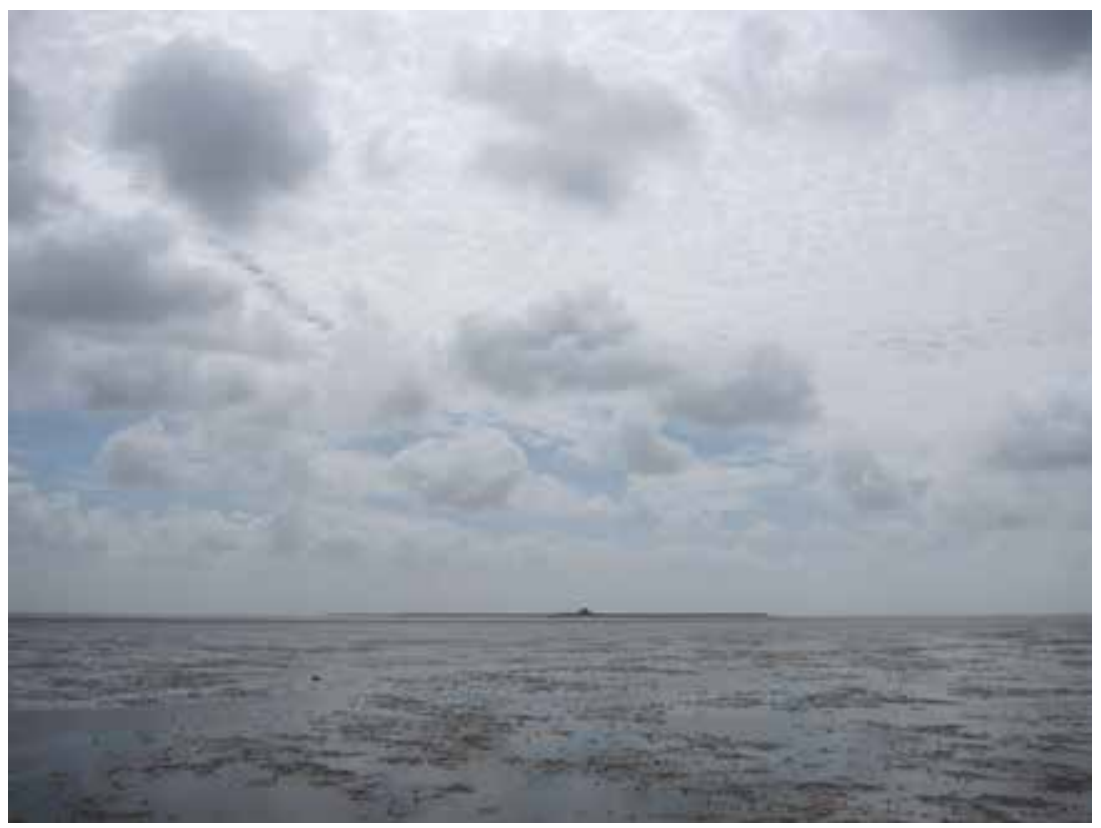

Photo by author

\section{Literary imagination}

Large parts of the Wadden Sea form a 'cemetery of the marshlands'. Storm tides have been responsible for thousands of deaths. They rank among the most devastating natural disasters of European history and have shaped the coasts significantly. Culture, economics, and social structures in the entire region have been influenced by them. Quite a few Frisian dialects have literally gone down into the sea. The great floods have etched themselves onto the collective memory of the people, such as the Rungholt Flood of 1362, which spawned tales, legends and poems. An entire generation of schoolchildren have learned Detlev von Liliencron's ballad Trutz blanke Hans by heart. Rungholt can be found in the work of Hans Christian Andersen, and Nobel Laureate Günter Grass wrote a poem about this mystical place.

There are other important artistic and literary works that have a connection to the Wadden Sea, too. In world literature, there is Theodor Storm's novel Der Schimmelreiter, which tells of dikemaster Hauke Haien, who, bringing new ideas, endeavours to transform wadden into dry land but in the end 
Figure 6.2 Wanderers on their way to Hallig Oland.

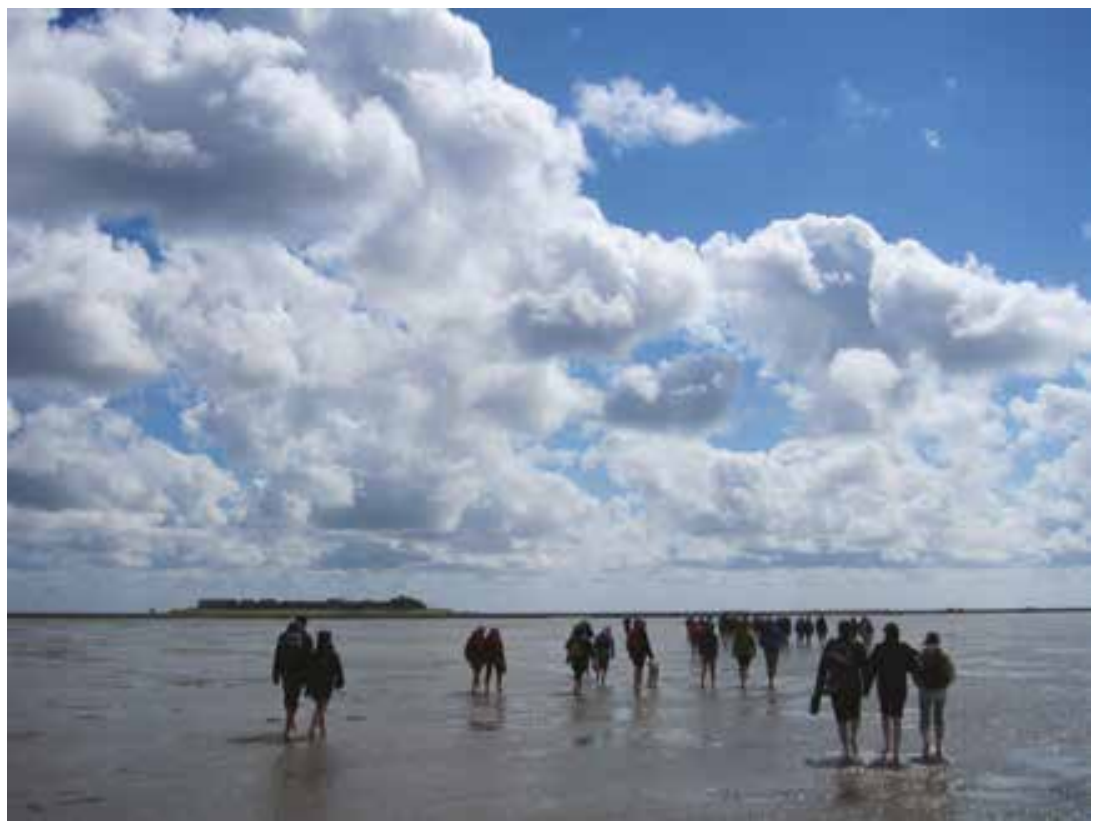

Photo by author

fails during a storm tide. Theodor Storm describes the mystical world of the ambivalent Wadden Sea in an impressive way. In his poem "Meeresstrand", the islands lie like dreams in mists upon the sea ('Wie Träume liegen die Inseln im Nebel auf dem Meer'), and he speaks mysteriously about voices that are over the deep ('Stimmen, die über der Tiefe sind'). Goethe himself mentioned man's struggle with the North Sea, although he does not refer to North Frisia but to Lower Saxony. In the second part of Faust, he writes that 'der Weisheit letzter Schluss' (wisdom's last verdict) lies at the coast of the Wadden Sea:

And in the centre here, a Paradise, whose boundaries hold back the raging tide,

And though it gnaws to enter in by force,

The common urge unites to halt its course.

Yes, I've surrendered to this thought's insistence,

The last word Wisdom ever has to say:

He only earns his Freedom and Existence,

Who's forced to win them freshly every day.

Whose boundaries hold back the raging tide... 
Since the Middle Ages, freedom has been associated with the Frisians, including by the Frisians themselves. It seems that it is also the North Frisian Wadden Sea where freedom dwells. In Storm's novel Eine Halligfahrt, a Hallig turns into a 'Ländchen der Freiheit' (little land of freedom). Another example of the Frisian sense of independence is Hermann Neuton Paulsen, owner of Süderoog; he considered leaving the Prussian State and achieving independence for his Hallig, which was no larger than one square kilometre (Klatt 2016).

\section{Traces of culture}

Traces of culture (Kulturspuren) - remains of terps and dikes, bricks, pottery shards, tidal gates, ditch systems, furrows, entire farming fields, places of early salt peat extraction — bear testament to the interdependence between man and nature. The archaeologist Hans Joachim Kühn considers this 'an inexhaustible archive of remembrance and research, sometimes even of shudder'. Everyday items found on the wadden provide us with knowledge of the living conditions of the past. Ceramic pots illustrate the connections with the Rhine area; coins allow us to draw conclusions about trade routes; skulls are reminders of the transience of life. Like the landscape, traces of culture are subject to the law of constant change, too. For a while they are visible, then they may be covered by silt or destroyed by the tidal current; others may appear in other places. Centuries ago, a medieval system of fields and farmland appeared north of Pellworm. Due to centuries of extended shaping, a system like this is no longer to be found anywhere behind the dikes but only in that submerged cultivated land.

The North Frisians' language is a testimony to their special connection with the Wadden Sea. One word can express something that English or German need several words for. 'To be surprised by the incoming tide', for example, is beflödje in Frisian. On the island of Föhr, waas refers to mudflats that can be walked on. If it smells of wadden, the noun is simply transformed into an adjective: At stiremt waasig.

\section{Economy}

Since the Frisians settled in this region, the wadden have been part of their life and their work. They went out to catch prawns (garnelen, krabben) with the help of the gliep, a net fastened to a wooden rack. Catching flatfish 
with the help of feet and hands was called buttpedden or buttgrappeln (Lorenzen 1992). As early as 1749, Lorenz Lorenzen described this in his Genaue Beschreibung der wunderbaren Insel Nordmarsch, noting that by collecting mussels 'arme Leute sich fast alle Zeit... des Hungers sich erwehren' ('poor people generally escape starvation'). The shells were used to fortify paths or were delivered to lime kilns. Eels and crabs were also caught by hand (Lorenzen 1982). It is often assumed that the North Frisians were a community of fishermen, but that was seldom the case. They mostly caught what they needed for themselves. Something else, however, was exported: 'Frisian salt', which was extracted from salt turf. Temporarily, the export of this salt provided a certain degree of economic prosperity.

In addition, they collected birds' eggs to enrich their menus - an atrocity in the eyes of modern-day conservationists. They supplemented their diet not only with animals but also plants from the Wadden Sea, for example the strandwegerich (plantago maritima) of the plantain family, which has a height of 10 to 30 centimetres. These 'Suden' are especially aromatic as a vegetable or in a salad because of their habitat on the upper salt marshes. The inhabitants of the Halligen in particular used to eat them and were therefore given the nickname sudenbieter (sudenbiter).

It was most natural for people to frequently travel the wadden on foot or on horseback. But it has been only in the last decades that walking on wadden or sometimes even prawn-catching with the gliep - has become a tourist activity. And its popularity is increasing. Led by trained guides, thousands of people are experiencing the unique world of wadden and Halligen every summer. We must not forget that tourism has become the most important source of income in North Frisia nowadays, and the underlying foundation of this industry is the wadden. In earlier times, it had been pure necessity and part of everyday life. It is worth remembering that the tideways, with a depth of 30 and more metres today, still could be crossed on foot in earlier centuries. A master churchbuilder is said to have reached his building sites on the islands of Sylt, Föhr and Pellworm on horseback. Several courageous marches across the wadden have gone down in North Frisian history (Holander 1973). In 1864, despite drifting ice, a word of homage adressing the Duke of Augustenborg was carried to the mainland across the wadden by two captains from the island of Sylt. People crossing the mudflats for a purpose like that were regarded as either heroes or traitors - depending on the national political attitude at the time.

Many an object has washed up to the beach by the sea. Much flotsam and jetsam have been retrieved not only along the coast but on the wadden and the sandbanks, too. And of all the world's coastlines, North Frisia — located 
Figure 6.3 Catching prawns with a 'Gliep'.

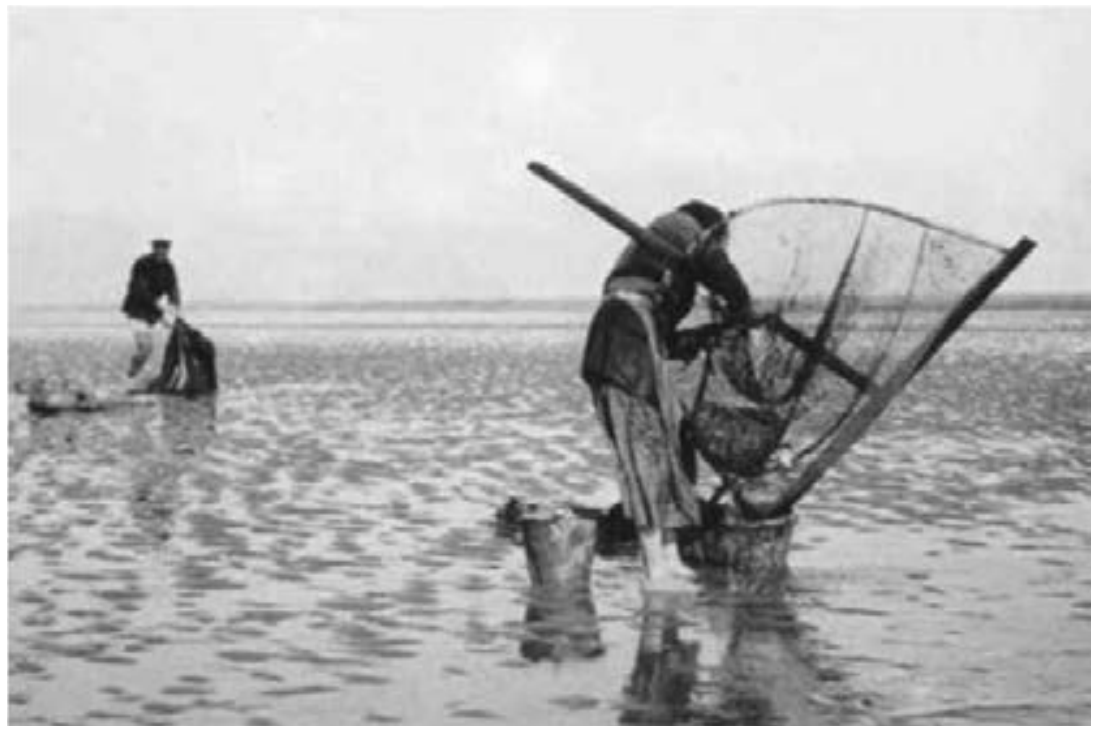

Photo by Ernst C. Payns, Nordfriisk Instituut

along the busy sailing route from the North Sea to the Baltic — is probably among the 'richest' in shipwrecks.

\section{Controversial conservation}

Throughout the centuries, there has been a special relationship between the North Frisians and the Wadden Sea. This is reflected in the intense discussions on the establishment of a national park. During the first detailed discussion on this issue in 1973-74, Willi Hansen, the mayor of Nordstrand and an acknowledged authority on the Wadden Sea, made his voice heard and said that the planned law on creating a national park would take away the 'age-old customary rights of the North Frisians' and 'their crucial competences'. He added that the Wadden Sea had been created by land loss and that therefore the inhabitants of the region may be the first to claim rights (Husumer Nachrichten, 27 December 1973).

Frederik Paulsen, chairman of the Verein Nordfriesisches Institut at that time, made a similar argument:

The Wadden Sea is not an original natural landscape but in large part a cultural landscape lost to the sea. So, in one form or the other, the Frisian 
inhabitants have paid for the Wadden Sea. That is why they primarily are entitled to decide about the Wadden Sea. In November 1973 alone, autumn storms caused a loss of about 10 meters at Goting and Utersum cliff and thereby enlarged the Wadden Sea correspondingly. Our normal sense of justice tells us that those suffering land loss must have a right in the Wadden Sea, a right that is stronger than that of the state, that of the Federation and that of the national and international nature conservation organizations.

He added that the Wadden Sea not only was a habitat of a great diversity of animals and plants but had also been 'the original habitat of the Frisian coastal community' for more than a thousand years. Paulsen considered it possible that scientific research could discover forms of economic use of the Wadden Sea, thereby providing the possibility for future generations to live in North Frisia (Husumer Nachrichten, 4 January 1974; see also his comment in Frisian 'At waas blaft üüs aanj', Husumer Nachrichten, 5 June 1976). Andreas Reinhardt, chairman of the Nordfriesischer Verein, feared that the establishment of a national park would lead to restrictions for the Frisian people and to stringent coastal protection as well. A stringent law, he argued, was not in harmony with a landscape that had been formed by the interplay of nature and man and which was under constant change (Husumer Nachrichten, 21 January 1974).

In a community assembly on the island of Pellworm, Johannes Jensen, the island's mayor, stated that no one on the island was in favour of a national park. He said that the people of Pellworm loved the island but also wanted to 'live and work' in this landscape in the same way as it had always been. He referred to the North Frisians as 'nature conservationists by birth'. However, it was the Frisian Georg Quedens from the island of Amrum who could not agree at all on this point: 'Most of the locals predominately considered native nature as something that should be made use of. The number of committed local conservationists, who maybe were willing to make sacrifices, has remained very low to this day' (Husumer Nachrichten, 15 June 1976).

Because of the numerous protests, the Schleswig-Holstein state government withdrew its first bill to establish the Wadden Sea National Park, and it took until 1985 for a new attempt to arise. Today, it can be stated that the majority of the North Frisians have not only made peace with the national park but also approve of it. 


\section{Cultural as well as natural heritage}

It does seem that people and organisations from outside North Frisia were the first to be active in the field of nature conservation in the Wadden Sea. Typically, the North Frisians themselves did not see the need for such an activity. One of the non-local activists was Gert Oetken (1932-2016), a dentist from Rendsburg who founded the first society for the protection of the Schleswig-Holstein part of the Wadden Sea (Schutzstation Wattenmeer). He also turned his attention to the Wadden Sea culture, an area other nature conservationists were, for the most part, not interested in. Another non-local conservationist who dedicated himself to protecting the Halligen as early as the end of the nineteenth century was Eugen Traeger (1855-1943), a librarian from Posen (Poznań). He wrote that the Wadden Sea with its Halligen was 'one of the most peculiar regions of the world'.

There have always been North Frisians who have turned to the Wadden Sea's history. The quintessential example is farmer Andreas Busch from Nordstrand, who may rightly be considered the man who discovered Rungholt (see the contribution by Hadler et al. in this volume). The man with the greatest knowledge of sources is Albert Panten, a teacher who was familiar with nearly every sunken parish. There have been islanders who worked as wadden guides and made extraordinary discoveries during their tours. One of them is Hellmut Bahnsen, whose finds from the wadden are exhibited in a museum on the island of Pellworm. Scientists exploring the Wadden Sea and its history from a professional perspective include Albert Bantelmann, Ernst Dittmer, Hans Joachim Kühn, Marcus Petersen and Erich Wohlenberg.

In general, however, a great deal remains to be done in this area. Obviously, the Land Office for Archeology in Schleswig is predominantly concerned with Viking sites, with Haithabu and the Danewerk on the east coast, which have been nominated as World Heritage Sites in their own right. The Wadden Sea along the west coast is being neglected. Using considerable finances to explore nature in and around the Wadden Sea has been, and continues to be, justified. However, at least some funding for the exploration of the North Frisian Wadden Sea's cultural heritage would be desirable (Steensen 2001). It would have been ideal if the Wadden Sea had been recognised in 2009 not only as a World Natural Heritage Site but also as a World Cultural Heritage Site. So far, this cultural landscape has not been given sufficient attention. 


\section{References}

Goethe, J.W. von (2003). Faust Parts I \& II. Retrieved from www.iowagrandmaster. org/Books\%2oin\%2opdf. Faust.pdf

Fischer, L. (ed.) (1997). Kulturlandschaft Nordseemarschen. Bräist/Bredstedt, Westerhever: Nordfriisk Instituut, Hever.

Holander, R. K. (1973). Von Porrenstriekern, Postläufern und anderen. Was heißt „friesische Wattläufertradition“? Nordfriesland 26, 93-100.

Klatt, G. (2016). Süderoog. Hallig im Wattenmeer. Bräist/Bredstedt: Nordfriisk Instituut.

LANCEWAD (2001). Landscape and Cultural Heritage in the Wadden Sea Region. Project Report.Wadden Sea Ecosystem No. 12, Wilhelmshaven: Common Waddensea Secretariat.

Lengsfeld, K. (1998). Halligleben um 19oo. Heide: Boyens.

Lorenzen, J. (1992). Die Halligen in alten Abbildungen. Eine Fotodokumentation über die Warften aus der 1. Hälfte des 20. Jahrhunderts, Bräist/Bredstedt: Nordfriisk Instituut.

Lorenzen, L. (1982). Genaue Beschreibung der wunderbaren Insel Nordmarsch 1749. Hamburg: Buske.

Müller, F. (1917). Das Wasserwesen an der schleswig-holsteinischen Nordseeküste. Teil 1: Die Halligen. Berlin: D. Reimer.

Petersen, M. (1981). Die Halligen. Küstenschutz - Sanierung - Naturschutz. Neumünster: Wachholtz.

Pingel, F. (2000). Leben mit Landunter: die Halligen. In: Thomas Steensen (ed.), Das große Nordfriesland-Buch, Hamburg: Ellert \& Richter, 454-461.

Quedens, G. (1975). Die Halligen. Breklum: Breklumer Verlag.

Riecken, G. (1982). Die Halligen im Wandel. Husum: Druck- und Verlagsgesellschaft.

Schroor, M. (2008). Waddenzee. Waddenland. Historische verkenningen rond de geografische identiteit en begrenzing van het internationale waddengebied. Leeuwarden: Raad voor de Wadden.

Steensen, T. (2001, June). Das Wattenmeer als Weltkulturerbe? Nordfriesland 134, $12-17$.

Steensen, T. (2008). Geschichte Nordfrieslands von 1918 bis in die Gegenwart (Geschichte Nordfrieslands, Teil 5). Bräist/Bredstedt: Nordfriisk Instituut.

Steensen, T. (2009). Im Zeichen einer neuen Zeit. Nordfriesland 1800 bis 1918 (Geschichte Nordfrieslands, Teil 4). Bräist/Bredstedt: Nordfriisk Instituut.

Storm, T. (1854). "Meeresstrand." Mainz University, http://www.staff.uni-mainz. de/pommeren/Gedichte/Storm/meeresst.htm.Accessed on January 26, 2018.

Timrott, F. and Timrott, J. (2013). Halligen - Entdecken und erleben. Neumünster: Wachholtz. 
Das Wattenmeer (2005). Kulturlandschaft vor und hinter den Deichen. Stuttgart: Konrad Theiss.

Umweltatlas Wattenmeer. Band 1: Nordfriesisches und Dithmarscher Wattenmeer (1998). Landesamt Schleswig-Holsteinisches Wattenmeer und Umweltbundesamt. Stuttgart: Eugen Ulmer.

Welterbe-Manual (2009). Handbuch zur Umsetzung der Welterbekonvention in Deutschland, Luxemburg, Österreich und der Schweiz. Bonn: Deutsche UNESCO-Kommission.

\section{About the author}

Prof. Thomas Steensen studied history, political science, Frisian philology and sociology at the University of Kiel. Since 1987, he has been director of the Nordfriisk Instituut in Bredstedt, the central scientific institution for the Frisian language and the culture and history of North Frisia. Since 1986, he has been lecturer at the Universities of Kiel and Flensburg and since 1999 honourary professor in Flensburg. He is a member of the organising committee of the conference 'Waddenland - Outstanding'. 